Jurnal Geografi, Edukasi dan Lingkungan (JGEL) Vol. 3, No. 2, Juli 2019:69-76

P-ISSN: 2579-8499; E-ISSN: 2579-8510

Doi: https://doi.org/10.29405/jgel.v3i2.3579

Website: http://journal.uhamka.ac.id/index.php/jgel

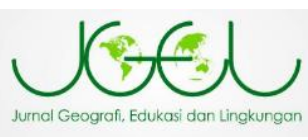

\title{
Sebaran Salinitas Air Tanah Bebas di Desa Pulogading Kecamatan Bulakamba Kabupaten Brebes Jawa Tengah
}

\author{
Zulai Fatul Baroroh*, Tricahyono Nur Harsono, Moch Balya Ali Sya'ban, dan Siti \\ Dahlia \\ Pendidikan Geografi, FKIP Universitas Muhammadiyah Prof. DR. Hamka, Jakarta \\ Timur, Indonesia
}

*E-mail: barorohzulaifatul99@gmail.com

Received: 20122018 / Accepted: 11042019 / Published online: 30072019

\begin{abstract}
ABSTRAK
Permasalahan penurunan kualitas air tanah akibat intrusi secara alami terjadi pada daerah pesisir, termasuk pada wilayah penelitian yaitu Desa Pulogading Kecamatan Bulakamba Kabupaten Brebes Jawa Tengah. Penelitian ini bertujuan untuk mengetahui tingkat salinitas air tanah bebas berdasarkan klasifikasi Zona Konservasi Air Tanah Departemen Energi dan Sumberdaya Mineral, dan bagaimana sebarannya di desa penelitian. Penelitian ini menggunakan metode survey-deskriptif. Pengambilan data primer dilakukan pada bulan Juli 2018 pada musim kemarau, dengan jumlah 18 titik sampel. Penentuan titik sampel menggunakan sistem grid dengan interval $750 \mathrm{~m}$. Data yang di peroleh berupa angka kadar salinitas berdasarkan $\% \mathrm{NaCl}$ dengan alat ukur saltmeter. Hasil penelitian menunjukkan bahwa kadar salinitas air tanah bebas di Desa Pulogading Kecamatan Bulakamba Kabupaten Brebes Jawa Tengah bervariatif. Sebagian besar $(72,2 \%)$ air tanah wilayah penelitian termasuk dalam kategori rawan, 16,7\% wilayah penelitian dengan kategori aman, dan 11,1\% merupakan kategori kritis. Selain itu, hasil penelitian menunjukkan bahwa kadar salinitas air tanah bebas dipengaruhi oleh cara pengambilan dan jenis penggunaan serta tutupan lahannnya.
\end{abstract}

Kata kunci : Salinitas, Air Tanah Bebas, Klasifikasi Zona Konservasi Air Tanah

\begin{abstract}
The problem of decrasing quality of groundwater is caused by intrusion with naturally is happening in coastal area, this situation also is occurring in Pulogading Village, Bulakamba Distric, Brebes Regency, Central Java. The aims of research to find out the unconfined groundwater salinity based on the classification of groundwater conservation zones from Department of Energy and Mineral Resources, and how the distribution in the research area. This analysis of research was used survey-descriptive method. Primary data collection was conducted in July 2018 during dry season with total of sampels ware 18. The sampling technique divided by grid-method with 750 metre of interval. The data obtained is in the unconfined groundwater salinity number levels based on \%NaCl using the saltmetre. The result of research showed that unconfined groundwater salinity levels in Pulogading village, Bulakamba, Brebes, Central Java is varied. The classification of groundwater conservation zones from Department of Energy and Mineral Resource, the type of groundwater sample in research area are safe, crisis and suscaptibility levels. The majority research area has Suscaptibility level (72,2\%), safe level is 16,7\%, and crisis level is 11,1\%. The unconfined groundwater salinity level is influenced by well penetrating method and the type of landused or landcover.
\end{abstract}


Keywords : Salinity, Unconfined Groundwater, The Classification of Groundwater Conservation Zones

\section{PENDAHULUAN}

Air merupakan elemen terpenting bagi kehidupan makhluk hidup di bumi. Air menjadi kebutuhan mutlak karena sebagian besar komponen pembentuk makhluk hidup terdiri dari air. Menurut Purwanto \& Susanto (2015), kandungan air di bumi pada dasarnya berlimpah, volume seluruhnya mencapai $1.400 .000 .000 \mathrm{~km}^{3}$, dengan komposisi 97\% merupakan air laut (air asin) yang tidak dapat dimanfaatkan secara langsung dalam kehidupan manusia, $2 \%$ berupa gunung-gunung es, $0,75 \%$ adalah air tawar yang berupa mata air, air sungai, air danau maupun air tanah dan selebihnya berupa uap air.

Selain Faktor kuantitas, faktor lainnya yang menentukan adalah kualitas (mutu) air. Mutu air dapat diamati dengan parameter fisik, kimia dan biologi. Berdasarkan parameter tersebut mutu air harus sesuai dengan standar peruntukannya. Menurut Effendi (2003), mengatakan kualitas air yaitu sifat air dalam kandungan makhluk hidup, zat, energi, atau komponen lain dalam air. Kualitas air dinyatakan dalam beberapa parameter, yaitu parameter fisika (suhu, kekeruhan, padatan terlarut dan sebagianya), parameter kimia ( $\mathrm{PH}$, oksigen terlarut, Biological Oxygent demand, kadar logam dan sebagainya) dan parameter biologi (plankton, bakteri dan sebagainya). Penurunan kualitas air tanah di wilayah pesisir diakibatkan oleh perembesan air laut. Perembesan air laut berdampak pada peningkatan kadar garam (salinitas) pada air tanah, karena air laut bercampur dengan kolom air tanah. Menurut Nontji (2007), mengemukakan bahwa salinitas dikenal dalam literatur oseanologi sebagai kadar garam atau kegaraman yang maksudnya ialah jumlah berat semua garam (dalam gram) yang terlarut dalam satu liter air.

Desa Pulogading Kecamatan Bulakamba Kabupaten Brebes terletak di wilayah Pulau Jawa bagian utara dan berbatasan langsung dengan Laut Jawa. Berdasarkan data monografi Desa Pulogading tahun 2017 mengenai prasarana air bersih dan sanitasi, jumlah sumur pompa terdapat 480 unit, sumur gali 203 unit, tanki air bersih 4 unit. Pemenuhan kebutuhan air bersih penduduk bersumber dari air tanah yang diambil melalui sumur gali dengan jumlah 406 keluarga, sedangkan pengambilan air tanahnya menggunakan sumur pompa sebanyak 13 keluarga. Jumlah keluarga pelanggan PAM (Perusahaan Air Minum) 833 Keluarga, jumlah keluarga menggunakan penampung air hujan 8 keluarga. Kondisi tersebut menunjukkan bahwa mayoritas masyarakat wilayah penelitian memanfaatkan air tanah untuk pemenuhan kehidupan sehari-hari. Akan tetapi, kondisi morfologi wilayah penelitian yang merupakan daerah pesisir berpotensi adanya instrusi air laut yang mempengaruhi air tanah wilayah penelitian. Berdasarkan hal tersebut, penelitian ini bertujuan untuk identifikasi mengenai sebaran salinitas di Desa Pulogading Kecamatan Bulakamba Kabupaten Brebes Jawa tengah ini guna mengetahui salinitas air tanah bebas berdasarkan klasifikasi Zona Konservasi Air Tanah Departemen Energi dan Sumberdaya Mineral.

\section{METODE PENELITIAN \\ Waktu dan Lokasi Penelitian}

Penelitian ini dilaksanakan di wilayah Desa Pulogading, Kecamatan Bulakamba, Kabupaten Brebes, Provinsi Jawa tengah. Letak astronomis wilayah 
penelitian yaitu $06^{0} 49^{\prime} 11,91^{\prime \prime}$ LS $06^{\circ} 51^{\prime} 11,69^{\prime \prime}$ LS dan $108^{0} 56^{\prime} 1,51^{\prime \prime} \mathrm{BT}$ $108^{\circ} 57^{\prime} 57,34$ ” BT (Gambar 1), dengan elevasi 0-10 $\mathrm{m}$ diatas permukaan laut (dpl). Berdasarkan data laporan tahunan Desa Pulogading (2017), bahwa luas wilayah Desa Pulogading 689,79 ha, wilayah penelitian merupakan daerah tanah timbul alami (tingkat sedimentasi relatif cepat), sehingga setiap tahun bertambah luasnya. Desa Pulogading dipilih sebagai area penelitian karena memiliki karakteristik wilayah pesisir dengan jarak pemukiman dengan laut adalah sekitar $1,5 \mathrm{~km}$. Waktu penelitian adalah Maret 2018 sampai dengan November 2018.

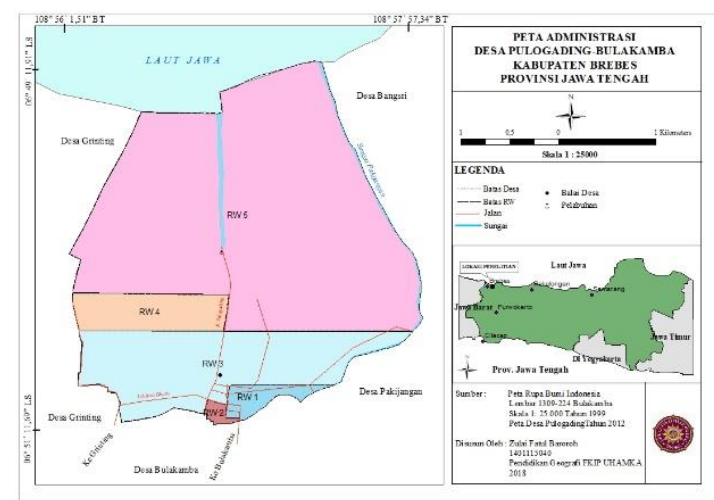

Gambar 1: Lokasi Penelitian

\section{Alat dan Bahan}

Alat dan bahan yang digunakan dalam penelitian ini disajikan pada Tabel 1.

Tabel 1. Alat dan Bahan Penelitian

\begin{tabular}{|l|l|l|}
\hline No & \multicolumn{1}{|c|}{ Alat/bahan } & \multicolumn{1}{|c|}{ Fungsi } \\
\hline 1. & Salt Meter & $\begin{array}{l}\text { Mengukur salinitas } \\
\text { air berdasarkan } \\
\% \text { NaCl }\end{array}$ \\
\hline 2. & $\begin{array}{l}\text { Thermometer } \\
\text { air }\end{array}$ & Mengukur suhu air \\
\hline 3. & TDS meter & $\begin{array}{l}\text { Mengukur padatan } \\
\text { terlarut }\end{array}$ \\
\hline 4 & Bor tanah & $\begin{array}{l}\text { Menggali/membuat } \\
\text { lubang pada tanah }\end{array}$ \\
\hline 5. & GPS & $\begin{array}{l}\text { Mengukur titik } \\
\text { koordinat dan } \\
\text { elevasi }\end{array}$ \\
\hline
\end{tabular}

\begin{tabular}{|l|l|l|}
\hline 6. & $\begin{array}{l}\text { Peta } \\
\text { topografi, } \\
\text { geologi, tanah }\end{array}$ & $\begin{array}{l}\text { Informasi } \\
\text { topografi, geologi } \\
\text { dan tanah }\end{array}$ \\
\hline 7. & $\begin{array}{l}\text { Citra Google } \\
\text { Earth }\end{array}$ & $\begin{array}{l}\text { Interpretasi } \\
\text { penggunaan lahan }\end{array}$ \\
\hline 8. & $\begin{array}{l}\text { Data } \\
\text { klimatoloogi }\end{array}$ & $\begin{array}{l}\text { Temperatur, curah } \\
\text { hujan, kelembaban }\end{array}$ \\
\hline 9. & $\begin{array}{l}\text { Monografi } \\
\text { desa }\end{array}$ & $\begin{array}{l}\text { Informasi fisik dan } \\
\text { demografi }\end{array}$ \\
\hline 10 & Arcgis & $\begin{array}{l}\text { Mengolah data } \\
\text { spasial }\end{array}$ \\
\hline
\end{tabular}

\section{Jenis Penelitian}

Penelitian mengenai analisis sebaran salinitas air tanah bebas ini merupakan penelitian survei dengan pendekatan deskriptif, yaitu dengan pengungkapan fakta-fakta di lapangan berdasarkan data hasil pengumpulan data primer maupun sekunder, serta dilakukan interpretasi dan juga analisis terkait faktafakta tersebut.

\section{Metode Pengumpulan, Pengolahan, dan Analisis Data}

Pada penelitian ini untuk pengambilan data sampel air tanah menggunakan 18 titik sampel. Metode pengambilan titik sampel menggunakan sistem grid dengan interval 750m (Gambar 2). Pengukuran kadar salinitas air tanah dalam penelitian ini menggunakan salt meter.

Pengolahan dan analisis data tingkat salinitas berdasarkan tabel klasifikasi salinitas Goetz (Tabel 2), dan standar klasifikasi zona konservasi air tanah Departemen Energi dan Sumber Daya Mineral (Tabel 3). 


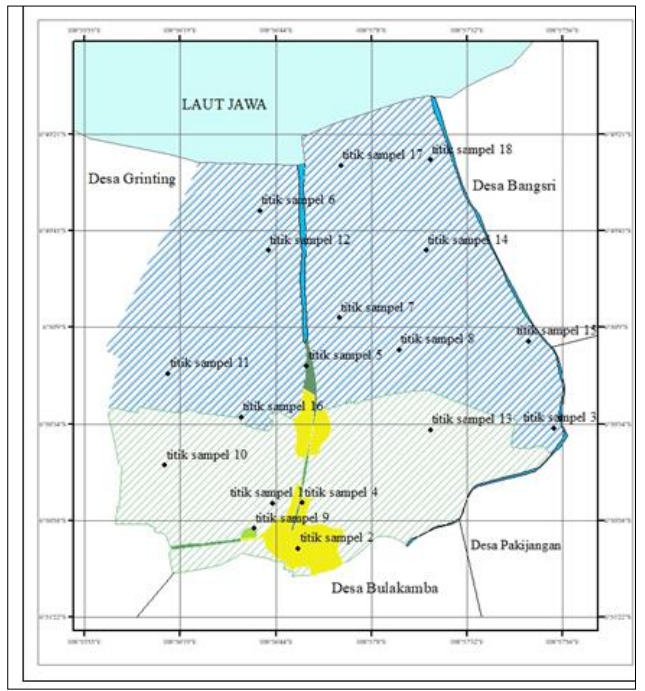

Gambar 2. Peta Persebaran Titik Sampel

Tabel 2. Klasifikasi Salinitas Goetz (1986)

\begin{tabular}{|c|c|c|}
\hline No & Salinitas \% & Klasifikasi \\
\hline 1 & $<0,05$ & Air Tawar \\
\hline 2 & $0,05-3,00$ & Air Payau \\
\hline 3 & $3,00-5,00$ & Air Asin \\
\hline 4 & $>5$ & Brine \\
\hline
\end{tabular}

Sumber: Budiyono, 2013

Tabel 3. Klasifikasi Zona Konservasi Air Tanah Berdasarkan Pertimbangan Penurunan Kualitas Air Tanahnya

\begin{tabular}{|c|c|l|}
\hline No & Zona & \multicolumn{1}{c|}{ Keterangan } \\
\hline 1 & Aman & $\begin{array}{l}\text { Kenaikan salinitas kurang } \\
\text { dari } 1000 \mathrm{mg} / \mathrm{l} \text { atau daya } \\
\text { hantar listrik kurang dari } \\
1000 \mu \mathrm{S} / \mathrm{cm} .\end{array}$ \\
\hline 2 & Rawan & $\begin{array}{l}\text { Kenaikan salinitas antara } \\
1000-10.000 \mathrm{mg} / \mathrm{l} \text { atau } \\
\text { daya hantar listrik antara } \\
1000-1500 \mu \mathrm{S} / \mathrm{cm} .\end{array}$ \\
\hline 3 & Kritis & $\begin{array}{l}\text { Kenaikan salinitas antara } \\
>10.000-15.000 \mathrm{mg} / \mathrm{l} \text { atau } \\
\text { daya hantar listrik antara } \\
>1500-5000 \mu \mathrm{S} / \mathrm{cm} .\end{array}$ \\
\hline 4 & Rusak & $\begin{array}{l}\text { Lebih dari } 100.000 \mathrm{mg} / \mathrm{l} \\
\text { atau daya hantar listrik } \\
\text { lebih dari } 5000 \mu \mathrm{S} / \mathrm{cm} \\
\text { atau tercemar oleh logam } \\
\text { berat dan atau bahan } \\
\text { berbahaya dan beracun. }\end{array}$ \\
\hline
\end{tabular}

\section{HASIL DAN PEMBAHASAN}

(Purnomo, Wahyudi, \& Suntoyo, 2013), mengatakan bahwa perkembangan penggunaan lahan khususnya pemukiman ataupun industri akan meningkatkan kebutuhan air bersih, yang tentunya akan terganggu jika tingkat intrusi semakin tinggi sehingga mempengaruhi kualitas air tanah. Penggunaan lahan wilayah penelitian masih didominasi oleh pertanian khususnya sawah padi irigasi di bagian selatan, dan tambak perikanan di bagian utara. Bentuk pemukiman memanjang dari utara ke selatan, dengan jarak pemukiman ke laut sekitar $2 \mathrm{~km}$. Pemukiman padat penduduk berjarak 2,5 $\mathrm{km}$ sampai dengan $3 \mathrm{~km}$ dari laut. Pemukiman padat bagian utara (jarak 2 $\mathrm{km}$ dari laut) memiliki drainase (permukaan resapan air) yang buruk. Hal tersebut dikarenakan adanya pengaspalan dan penutupan permukaan tanah dengan batu-bata atau paving conblock yang merata.

Pada penelitian ini sampel air tanah yang digunakan terdiri dari 18 titik sampel, yang diambil dari sumur-sumur warga dan fasilitas sosial. Sebanyak 15 sumur warga dan 3 sumur fasilitas sosial seperti TPI (Tempat Pelelangan Ikan), masjid dan balai desa. Pengambilan sampel pada kondisi cuaca cerah di musim kemarau. Pengambilan sampel air tanah dilakukan pada area dengan elevasi berfariasi yaitu 1 mdpl sampai 6 mdpl. Wilayah terendah adalah wilayah pasang-surut utara (sampel 17 dan 18) yaitu $1 \mathrm{mdpl}$ dengan koordinat 6 49'28,9" LS-108 57'00,2" BT dan $6^{\circ} 49^{\prime} 27,5^{\prime \prime}$ LS -108 $57^{\prime} 23,2$ " BT yang berbatasan langsung dengan Laut Utara Jawa. Wilayah ini merupakan areal terdampak langsung pasang surut. Wilayah tertinggi adalah masjid (sampel 2) yang dikelilingi oleh pemukiman, wilayah ini memiliki elevasi 6 mdpl (Tabel 4). 
73 | Jurnal Geografi, Edukasi dan Lingkungan (JGEL) Vol. 3, No. 2, Juli 2019:69-76

Tabel 4. Hasil Pengukuran Tingkat Salinitas Air Tanah

\begin{tabular}{|c|c|c|c|c|}
\hline Sampel & $\begin{array}{l}\text { Salinitas } \\
(\% \mathrm{NaCl})\end{array}$ & Salinitas ppm NaCl & Klasifikasi Salinitas & $\begin{array}{c}\text { Keterangan Lokasi } \\
\text { Pengambilan Sampel }\end{array}$ \\
\hline 1 & 0,2 & 2000 & $\begin{array}{l}\text { Air Payau (Brackish } \\
\text { Water) }\end{array}$ & $\begin{array}{l}\text { Pemukiman } \\
\text { (sumur gali) }\end{array}$ \\
\hline 2 & 0,1 & 1000 & $\begin{array}{l}\text { Air Payau (Brackish } \\
\text { Water) }\end{array}$ & Masjid (sumur gali) \\
\hline 3 & 0,0 & 0 & Air Tawar (Fresh Water) & Sawah (sumur bor) \\
\hline 4 & 0,3 & 3000 & $\begin{array}{l}\text { Air Payau (Brackish } \\
\text { Water) }\end{array}$ & $\begin{array}{l}\text { Balai Desa } \\
\text { (sumur bor) }\end{array}$ \\
\hline 5 & 0,2 & 2000 & $\begin{array}{l}\text { Air Payau (Brackish } \\
\text { Water) }\end{array}$ & TPI (sumur bor) \\
\hline 6 & 0,3 & 3000 & $\begin{array}{l}\text { Air Payau (Brackish } \\
\text { Water) }\end{array}$ & Tambak (sumur bor) \\
\hline 7 & 0,1 & 1000 & $\begin{array}{l}\text { Air Payau (Brackish } \\
\text { Water) }\end{array}$ & $\begin{array}{l}\text { Peternakan } \\
\text { (pompa/bor) }\end{array}$ \\
\hline 8 & 0,0 & 0 & Air Tawar (Fresh Water) & Sawah (sumur gali) \\
\hline 9 & 0,4 & 4000 & $\begin{array}{l}\text { Air Payau (Brackish } \\
\text { Water) }\end{array}$ & $\begin{array}{l}\text { Pemukiman } \\
\text { (sumur bor) }\end{array}$ \\
\hline 10 & 0,0 & 0 & Air Tawar (Fresh Water) & Sawah (sumur gali) \\
\hline 11 & 0,3 & 3000 & $\begin{array}{l}\text { Air Payau (Brackish } \\
\text { Water) }\end{array}$ & Tegalan (sumur bor) \\
\hline 12 & 0,4 & 4000 & $\begin{array}{l}\text { Air Payau (Brackish } \\
\text { Water) }\end{array}$ & Tambak (sumur bor) \\
\hline 13 & 0,1 & 1000 & $\begin{array}{l}\text { Air Payau (Brackish } \\
\text { Water) }\end{array}$ & $\begin{array}{l}\text { Lahan kering } \\
\text { (sumur bor) }\end{array}$ \\
\hline 14 & 0,5 & 5000 & $\begin{array}{l}\text { Air Payau (Brackish } \\
\text { Water) }\end{array}$ & Tambak (sumur bor) \\
\hline 15 & 0,1 & 1000 & $\begin{array}{l}\text { Air Payau (Brackish } \\
\text { Water) }\end{array}$ & sawah (sumur gali) \\
\hline 16 & 0,1 & 1000 & $\begin{array}{l}\text { Air Payau (Brackish } \\
\text { Water) }\end{array}$ & Sawah (sumur gali) \\
\hline 17 & 5,5 & 55000 & Brine & Wilayah pasang-surut \\
\hline 18 & 5,5 & 55000 & Brine & Wilayah pasang-surut \\
\hline
\end{tabular}

Berdasarkan hasil pengukuran sampel air tanah dilapangan pada Tabel 4 menunjukkan bahwa adanya variasi nilai salinitas yaitu $0,0 \% \mathrm{Nacl}$ sampai dengan $5,5 \%$ Nacl. Nilai salinitas terendah 0,0 $\%$ Nacl yaitu pada wilayah persawahan, pada elevasi 3 sampai 4 mdpl, dengan jenis pengambilan air yaitu sumur bor dan sumur gali. Nilai tertinggi yaitu $5,5 \%$ pada wilayah terdampak pasang-surut air laut dan memiliki elevasi $1 \mathrm{mdpl}$.

Analisa menggunakan metode regresi linier menemukan bahwa jarak sumur terhadap pantai memiliki hubungan linier, yaitu secara umum nilai salinitas menurun bila jaraknya menjauhi pantai (Nasjono, 2010). Hal ini berbeda dengan hasil penelitian yang menunjukkan bahwa terdapat beberapa sampel persebaran air payau lebih banyak kearah selatan, dan tingkat salinitasnya cenderung meningkat pada area yang menjauhi pantai. Hal ini dapat di identifikasi pengaruh faktor penggunaan lahan yang mayoritas merupakan pemukiman.

Berdasarkan klasifikasi sampel air tanah menurut zona konservasi air tanah Departemen Energi dan Sumber Daya Mineral wilayah penelitian memiliki tiga jenis zona klasifikasi yaitu aman, rawan dan kritis (Tabel 4.5). Sampel dengan zona aman kadar salinitasnya adalah $0 \mathrm{mg} / \mathrm{l}$ pada sampel 3,8 dan 10. Ketiga jenis sampel klasifikasi aman merupakan wilayah persawahan yang cenderung tergenang oleh air tawar secara berkala, 
selain itu jenis pengambilan air pada air persawahan adalah dengan sumur gali.

Sampel dengan kategori klasifikasi rawan dengan kadar salinitas bervariasi yaitu $1000 \mathrm{mg} / \mathrm{l}, 2000 \mathrm{mg} / \mathrm{l}, 3000 \mathrm{mg} / \mathrm{l}$, $4000 \mathrm{mg} / \mathrm{l}$ dan $5000 \mathrm{mg} / \mathrm{l}$ pada titik sampel $1,2,4,5,6,7,9,11,12,13,14,15,16$. Jenis penggunaan lahan pada sampel yaitu pemukiman, masjid, balai desa, TPI, tambak, peternakan, tegalan, lahan kering. Indikasi kondisi salinitas yang bervariasi yaitu intensitas pengambilan air yang cenderung tinggi di pemukiman. Teknik pengambilan air yang mendominasi adalah dengan sumur bor, selain itu kedalaman sumur bor relatif sangat dalam yaitu sekitar 40-120 m, sedangkan lapisan air tawar cenderung lebih dekat dengan permukaan tanah.

Sampel dengan kategori kritis dengan nilai salinitas $55000 \mathrm{mg} / \mathrm{l}$ adalah wilayah yang berbatasan langsung dengan laut, sehingga memiliki nilai salinitas yang tinggi. Sampel dengan nilai kritis yaitu pada titik sampel 17 dan 18 .

Tabel 5. Klasifikasi Zona Konservasi Air Tanah di Wilayah Penelitian

\begin{tabular}{|c|l|l|l|}
\hline Sampel & $\begin{array}{c}\text { Salinitas } \\
(\mathbf{p p m}) \mathbf{N a C l}\end{array}$ & $\begin{array}{c}\text { Klasifikasi Zona } \\
\text { Konservasi Air Tanah }\end{array}$ & \multicolumn{1}{|c|}{ Keterangan } \\
\hline 1 & 2000 & Rawan & Pemukiman (sumur gali) \\
\hline 2 & 1000 & Rawan & Masjid (sumur gali) \\
\hline 3 & 0 & Aman & Sawah (sumur bor) \\
\hline 4 & 3000 & Rawan & Balai Desa(sumur bor) \\
\hline 5 & 2000 & Rawan & TPI (sumur bor) \\
\hline 6 & 3000 & Rawan & Tambak (sumur bor) \\
\hline 7 & 1000 & Rawan & Peternakan (pompa/bor) \\
\hline 8 & 0 & Aman & Persawahan (sumur gali) \\
\hline 9 & 4000 & Rawan & Pemukiman (sumur bor) \\
\hline 10 & 0 & Aman & Persawahan (sumur gali) \\
\hline 11 & 3000 & Rawan & Tegalan (sumur bor) \\
\hline 12 & 4000 & Rawan & Tegalan (sumur bor) \\
\hline 13 & 1000 & Rawan & Lahan kering (sumur bor) \\
\hline 14 & 5000 & Rawan & Tambak(sumur bor) \\
\hline 15 & 1000 & Rawan & sawah (sumur gali) \\
\hline 16 & 1000 & Rawan & Sawah (sumur gali) \\
\hline 17 & 55000 & Kritis & Wilayah pasang-surut \\
\hline 18 & 55000 & Kritis & Wilayah pasang-surut \\
\hline
\end{tabular}

Berdasarkan Tabel 5, air tanah di wilayah penelitian sebagian besar masuk kedalam kategori rawan sebanyak 13 titik sampel dari 18 titik sampel atau sebanyak $72,2 \%$. Kategori aman sebanyak 3 titik sampel atau $16,7 \%$, dan kategori kritis sebanyak 2 titik sampel atau $11.1 \%$. Penggunaan lahan di wilayah yang termasuk kedalam zona rawan adalah pemukiman, masjid, balai desa, TPI, tambak, peternakan, tegalan,lahan kering, tambak, sawah.
Sebaran salinitas secara umum, semakin jauh air tanah dengan laut maka nilai salinitasnya semakin rendah, dan semakin dekat air tanah dengan laut maka salinitasnya semakin tinggi. Pada penelitian ini beberapa sampel mengalami anomali, yaitu terdapat sampel dengan jenis air tanah tawar pada wilayah penelitian dengan posisi di tengah bagian utara, wilayah tengah bagian timur dan wilayah tengah bagian barat-selatan. Penggunaan lahan pada ketiganya adalah persawahan. Anomali terjadi pada sampel 
wilayah bagian selatan yang jaraknya relatif jauh dari laut memiliki salinitas yang lebih tinggi dibanding wilayah tengah bagian agak ke utara. Anomali pada sampel wilayah selatan yang relatif jauh dari laut dapat di indikasi karena intensitas pengambilan air tanah yang relatif tinggi, jenis tutupan lahan yang menurunkan infiltrasi air hujan dan pengambilan air tanah. Peta dan grafik sebaran tingkat salinitas disajikan pada Gambar 3 dan 4.

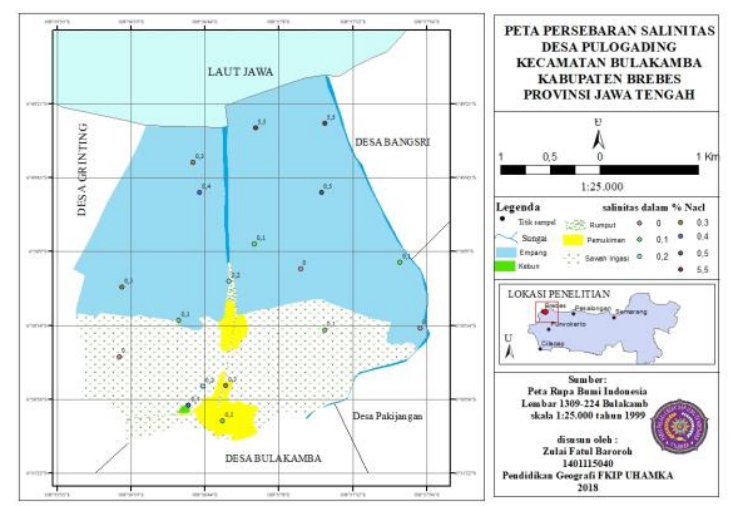

Gambar 3. Peta sebaran salinitas Pulogading

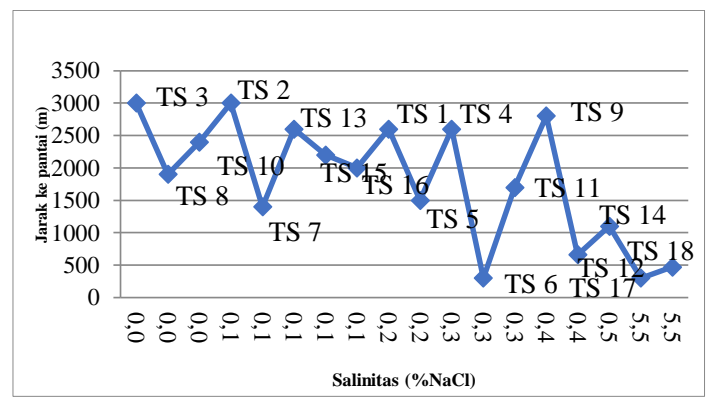

Gambar 4. Grafik hubungan jarak pantai dan salinitas

Intensitas pengambilan air di wilayah pemukiman cenderung lebih tinggi karena pemenuhan kebutuhan sanitasi penduduknya. Teknik pengambilan air tanah sebagian besar menggunakan sumur bor yaitu pada sampel selatan bagian timur, selatan bagian tengah, tengah sedikit ke utara, utara bagian barat, tengah sedikit ke timur laut, selatan bagian tengah, tengah bagian barat, utara bagian barat sedikit ke selatan, tengah agak ke timur dan utara agak ke timur, sedangkan 3 sampel air tanah dengan kategori tawar pengambilan airnya menggunakan sumur gali. Hal tersebut dapat dipengaruhi oleh lapisan air tawar pada akifer berada diatas lapisan air asin. Pengambilan air tanah dengan sumur gali kedalamannya bervariasi $4 \mathrm{~m}$ sampai dengan $6 \mathrm{~m}$. Menurut wawancara dengan penduduk, pengambilan air tanah menggunakan bor memiliki kedalaman 40 sampai dengan $120 \mathrm{~m}$.

Intrusi pada wilayah tersebut dimungkinkan terjadi akibat eksploitasi air tanah, sehingga terjadi penurunan muka air tanah tawar dan mendekati zona interface (zona air payau). Hal tersebut dikarenakan massa jenis air asin lebih berat dari air tawar, sehingga zona air tawar berada diatas zona air asin. Zona interface merupakan zona pencampuran/pertemuan antara zona air tawar dengan air asin.

Delinom (2007) mengatakan bahwa pengambilan air dengan cara pembuatan sumur gali akan mempercepat terjadinya penurunan muka air di titik tersebut, sehingga air asin yang ada dibawahnya akan ikut terambil. Kesulitan pengambilan air tanah dapat juga disebabkan oleh cara pengambilan tanah yang kurang tepat. Teknik pengambilan air tanah dengan pembuatan sumur gali, karena dinding sumur umumnya adalah pasir yang mudah runtuh, dinding sumur disemen dari atas sampai bawah. Dengan demikian, air tanah yang berada pada bagian atas tidak bisa masuk kedalam sumur, air yang terambil justru yang masuk dari bagian bawah sumur (air asin).

\section{KESIMPULAN}

Salinitas air tanah di wilayah Desa Pulogading memiliki nilai $0,0 \% \mathrm{NaCl}$ sampai dengan 5,5\% NaCl. Berdasarkan zona konservasi air tanah Departemen Energi dan Sumber Daya Mineral masuk kedalam 3 kategori yaitu rawan 72,2\%, aman $16,7 \%$ dan kritis $11.1 \%$. Kategori air 
yang mendominasi adalah air payau dengan penggunaan lahan sebagai pemukiman, masjid, balai desa, TPI, tambak, peternakan, tegalan dan lahan kering. Kategori air tawar penggunaan lahannya sebagai sawah. Kategori air asin (brine) adalah wilayah pasang-surut.

Anomali terjadi pada titik sampel wilayah bagian selatan yang jaraknya relatif jauh dari laut memiliki salinitas yang lebih tinggi dibanding wilayah yang relative dekat dengan laut. Indikasi anomali karena intensitas pengambilan air tanah yang relatif tinggi, drainase yang buruk, infiltrasi air hujan rendah dan teknik atau cara pengambilan air tanah. dengan bor.

\section{DAFTAR PUSTAKA}

Delinom, R. (2007). Sumber Daya Air di Wilayah Pesisir dan Pulau - Pulau Kecil di Indonesia. Jakarta : LIPI Press.

Effendi, H. (2003). Telaah Kualitas Air Bagi Pengelolaan Sumber Daya dan Lingkungan Perairan. Yogyakarta : kanisius.

Hutabarat, S dan Evans. (1984). Pengantar Oseanografi. Depok : UI-Press

Kodoatie, R. (2012). Tata Ruang Air. Yogyakarta: penerbit Andi.

Nasjono, J. K. (2010). Pola Penyebaran Salinitas Pada Akuifer Pantai Pasir. Jurnal Bumi Lestari, 10(2), 263-269.

Purnomo, N. A., Wahyudi, \& Suntoyo. (2013). Studi Pengaruh Air Laut Terhadap Air Tanah Di Wilayah Pesisir Surabaya Timur. Jurnal Teknik POMITS, 1(1), 1-6.
Sosrodarsono, S dan Kensaku. (1993). Hidrologi Untuk Pengairan. Jakarta : Pradnya Paramita

Tika, M. (2005). Metode Penelitian Geografi. Jakarta : PT Bumi Aksara.

Triatmodjo, B. (2012). Perencanaan Bangunan Pantai. Yogyakarta : Beta Offset.

Todd. (1980). Groundwater Hidrology. New York: John Wiley \& Sons Inc

Yunus, H. (2010). Metodologi Penelitian Wilayah Kontemporer. Yogyakarta: Pustaka Pelajar. 